\title{
Influence of Agro-pastoral Activities on Land Use and Land Cover Change in Karamoja, Uganda
}

\author{
S. Muwanga ${ }^{1,2}$, R. N. Onwonga ${ }^{2}$, S. O. Keya ${ }^{2}$ \& E. Komutunga ${ }^{3}$ \\ ${ }^{1}$ Nabuin Zonal Agricultural Research and Development Institute, National Agricultural Research Organisation, \\ Uganda \\ ${ }^{2}$ Department of Land Resources Management and Agricultural Technology, College of Agriculture and \\ Veterinary Sciences, University of Nairobi, Kenya \\ ${ }^{3}$ National Agricultural Research Laboratories, National Agricultural Research Organisation, Uganda \\ Correspondence: S. Muwanga, Nabuin Zonal Agricultural Research and Development Institute, National \\ Agricultural Research Organisation, Uganda. Tel: 256-772-567-642. E-mail: muwangantambi@gmail.com; \\ nsmuwanga@yahoo.co.uk
}

Received: October 24, 2018

Accepted: July 15, $2020 \quad$ Online Published: August 15, 2020

doi:10.5539/jas.v12n9p266

URL: https://doi.org/10.5539/jas.v12n9p266

\begin{abstract}
The land use and/or land cover changes (LULCC) caused mainly by human beings for their benefits play a pivotal role in a global environment, resulting in significant ecosystem changes. Iriiri, Matany and Rengen sub-counties in Karamoja sub-region of Uganda have undergone rapid LULCC in the past three decades. Nevertheless, the extent to which these changes have occurred have not been quantified. Establishing the extent of LULCC in the study area between 1986 and 2015 formed our objective. Supervised LANDSAT image classification for years 1986, 1996, 2005 and 2015 was done using ENVI 4.7 software. The classification resulted into six land use classes; Bareland, Farmland, Woodland, Grassland, Settlement, and Wetland. The area under each LULCC was subjected to a change detection analysis using Arc-GIS (ESRI, 2009) in ten years strata. The results revealed that settlement in Iriiri expanded significantly $(\mathrm{p}<0.05)$ by $71.3 \%$, while farmland increased by $45 \%$. Woodland and grassland significantly $(\mathrm{p}<0.05)$ declined by $68 \%$ and $30 \%$ respectively. Bareland increased by $56 \%$, while wetland decreased by $54 \%$. Woodland and grassland significant $(\mathrm{p}<0.05)$ shrunk by $87 \%$ in Matany and Rengen sub-counties. Farmland expanded significantly $(\mathrm{p}<0.05)$ by $147 \%$ and Woodland shrunk significantly $(\mathrm{p}<0.05)$ by $79 \%$ in Rengen sub-county. Generally, farmland and settlement increased while woodland and grassland shrunk due increased human population and farming. Expansion of farming is partially due to increased human settlement to pursue agriculture following advocacy by the government of Uganda. The removal of natural vegetation is expected to negatively impact soil quality by exposing it to agents of erosion. However, the extent of these impacts is unknown. Hence, further studies on LULCC and their impact on soil quality at sub-counties level are crucial in guiding land use policy and sustainable management practices in the area.
\end{abstract}

Keywords: agro-pastoral; Karamoja, LANDSAT image classification, change detection analysis, land use land cover change

\section{Introduction}

Karamoja sub-region is comprised of three agricultural zones namely; pastoral, agricultural and agro-pastoral. The agro-pastoral zone which run through the districts of Kabong, Kotido, Napak and Nakapiripirit, is one of the three main livelihood zones of Karamoja (USAID, 2017). The zone is mainly composed of the grassland, woodland farmland, and seasonal wetlands (Egeru et al., 2015). The grasslands provide pasture for livestock and are source of thatching material for traditional huts (cluster homesteads Manyata). The woodlands is known to be in its ecological balance for flora and fauna (Islam et al., 2016; Fox et al., 2017). They provide important ecosystem services, by regulating nutrient cycling, maintaining the hydrologic cycle and maintaining soil quality (Lawrance et al., 1997; Fan et al., 2007; Hassan et al., 2016).

The expansion of farmland, overgrazing by livestock, and human settlement are repeatedly cited as some of the dynamic force behind woodland shrinking in sub-Saharan Africa (Cui et al., 2013; Fox et al., 2017). The Land use changes which are often orchestrated by human beings, have negative effects to ecosystems, resulting in global 
climatic changes (Dirmeyer et al., 2010). Currently, LULCC studies are deemed as the main ways man can deal with and/or monitor natural resources for better environmental status (Fox et al., 2017). Worldwide, intact vegetation, for instance, forests/woodland and grassland are shrinking in size. Declining trends in the land cover with profound environmental consequences have been indicated in several studies (Rugadya \& Kansiime, 2013). For instance, deforestation and grassland cover removal for grazing and cultivation in Bangladesh led to a loss of biodiversity, soil quality, escalated global warming and enhanced natural disasters. Some of the negative consequences were, unpredictable rainfall patterns, prolonged drought and torrential rainfall (Islam et al., 2001; Islam et al., 2016). The unguided LULCC can be attributed to the increasing population coupled with socio-economic needs and political policies (Sundarakumar et al., 2012).

Globally, natural vegetation and grasslands are shrinking therefore leading to profound environmental consequences. Thus LULCC studies are imperative as the cheapest and quickest way of understanding the current state and predicting the future condition of socio-ecological landscapes (SELs) as influenced by man and nature. Further, studies on land cover changes, are crucial as a basis for in-depth socio-scientific re-assessments to better inform land users, planner, policy makers, and scholars (Sundarakumar et al., 2012s). It provides a realistic basis for designing suitable soil conservation technologies.

The magnitude of LULCC within small-ecological settings have been neglected. For instance, Iriiri, Matany and Rengen sub-counties have undergone swift LULCC in the past three decades. However, there are no studies related to LULCC at the sub-counties level. Hence, there is hardly reliable empirical data of land use changes at sub-county level in Karamoja. In order to bridge this knowledge gap, the objective was set to establish the extent of land use and land cover changes in Iriiri, Matany and Rengen sub-counties, Karamoja, from 1986 to 2015. It was hypothesised that, significant LULCC have occurred in the agro-pastoral, Karamoja for the last thirty years.

Such studies are necessary as a basis for in depth ecological, socio-scientific, economic reassessments to better inform land managers, and policy makers for the purpose of constituting sustainable land management practices.

\section{Materials and Methods}

\subsection{Study Site Description}

The study was conducted in two districts (Kotido and Napak) of the semi-arid Karamoja, Uganda which lies between latitude $1^{\circ}-4^{\circ}$ north and longitudes $33^{\circ}-35^{\circ}$ east. The districts of Kotido and Napak in the agro-pastoral Karamoja semi-arid sub-region which is located about $494.6 \mathrm{~km}$ (10 h drive) NE of Kampala, Uganda were chosen for the study. They were considered for the study because they were in the agro-pastoral zone and easily accessible for ground truthing. Kotido district is located $03^{\circ} 31^{\prime} \mathrm{N}, 34^{\circ} 07^{\prime} \mathrm{E}$. It has a population of 236,900 with a population density of $65.5 / \mathrm{km}^{2}$ (UBOS, 2016). Napak district is located along $02^{\circ} 12^{\prime} \mathrm{N}, 34^{\circ} 18^{\prime} \mathrm{E}$ and at $1500 \mathrm{~m}$ above the sea level. According UBOS (2014), its population stands at 197,700 with a population density of $39.7 / \mathrm{km}^{2}$. One sub-county (Rengen) and two (Iriiri and Matany) from each district of Kotido and Napak respectively were considered for the study. In addition, the sites were selected because they had three clear land uses; woodland, grazing land or grassland and farmland (smallholder farms). The area receives unreliable uni-model rainfall averaging between (500-760 mm) minimum and a maximum of (800-1000 mm) year ${ }^{-1}$ (Mubiru, 2010; Kyagulanyi et al., 2016). The average monthly minimum and the maximum temperature range between $15-18{ }^{\circ} \mathrm{C}$ and $28-32.4$ ${ }^{\circ} \mathrm{C}$, respectively (Mubiru, 2010). It has a very high evaporation rate greater than rainfall received (Kyagulanyi et al. 2016). The average wind speed is $12 \mathrm{~km} \mathrm{hr}^{-1}$. On estimate, Karamoja receives 10 hours of shine a day (hours when the sun is not obscured by clouds) (Weather 2, 2018).

\subsection{Data Collection for Land Use Land Cover Changes (LULCC)}

Extraction of LULCC information for the sub-counties satellite data processing was used (Table 1). The process involved scrutiny of LANDSAT Thematic Mapper (TM) together with the Enhanced Thematic Mapper (ETM) sub-counties images for period from 1986 to 2015 obtained from the United States Geological Survey website (USGS). The imageries used covered a 30 year period in ten years' intervals (1986, 1996, 2005 and 2015). The period of 10 year's interval was considered to be long enough for substantial LULCC in the area. Ground truthing was conducted in order to aid supervised classification of the images (ESRI, 2009).

\subsection{Classification of Image and Land Use and Cover Change Detection}

The Images were pre-processed by registration and sub-setting using ground control points (GCPS) (Mwavu \& Witkowski, 2008). This was followed by undertaking image classification starting with unsupervised classification through comparing individual pixel to each distinct cluster to see which one was closest to in order to derive the available classes. The supervised land image classification was then done through multi-temporal LANDSAT data processing using ENVI 4.7 software. The classification resulted into six (6) LULCC categories upon confirmation 
from ground truthing data (Tables 2, 4 and 6). The LULCC detection analysis was done for each land cover class on Arc-GIS (ESRI, 2009) to determine the area under each land use or cover type. The LULCC detection analysis was done using the images of $(1986,1996),(1996,2005)$ and $(2005,2015)$. Two images, each from different time (1986 to 1996 ; 1996 to $2005 ; 2005$ to 2015 and; 1986 to 2015), were used to analyse changes for classified LULCC types. The two sets of classified data enabled LULCC matrix operation to show all the possible changes between classes (Tables 2, 4 and 6). To test the significance in LULCC, the Chi-square goodness of fit test was performed using the SPSS 24 version and results are presented in (Tables 3, 5 and 7).

Table 1. Satellite images used for Matany and Rengen sub-counties of Karamoja digital image processing

\begin{tabular}{lllll}
\hline Year & Satellite & Path/row & Spatial resolution (m) & Date \\
\hline \multirow{3}{*}{1986} & Landsat-5 & $171 / 58$ & 30 & $10-01-1986$ \\
& Landsat-5 & $170 / 58$ & 30 & $04-02-1986$ \\
& Landsat-5 & $170 / 59$ & 30 & $18-10-1986$ \\
1996 & Landsat-5 & $171 / 58$ & 30 & $19-01-1996$ \\
& Landsat-5 & $170 / 58$ & 30 & $08-01-1996$ \\
2005 & Landsat-5 & $170 / 58$ & 30 & $10-01-1996$ \\
& Landsat-7 & $171 / 58$ & 30 & $02-2-2005$ \\
\hdashline & Landsat-7 & $170 / 58$ & 30 & $03-03-2005$ \\
2015 & Landsat-7 & $170 / 58$ & 30 & $15-03-2015$ \\
& Landsat-8 & $171 / 58$ & 30 & $15-03-2015$ \\
& Landsat-8 & $170 / 58$ & 30 & $03-01-2015$ \\
\hline
\end{tabular}

\section{Results}

\subsection{Land Cover Classification Scheme}

Variation in the degree of LULCC of Iriiri, Matany and Rengen sub-counties of Karamoja sub-region of Uganda from 1986 to 2015 at 10-year strata are presented in Tables 2 and 4 and 6. Their mosaics shown in Figures 1, 2 and 3 (Maps A, B, C, and D).

\subsection{Land Use and Land Cover Change}

The LULCC maps for Iriiri, Matany and Rengen for the year 1986, 1996, 2005 and 2015 (Figures 1, 2 and 3 plates A, B, C, and D) were generated following the LANDSAT image analysis and classification. Different land use or cover types in Iriiri, Matany and Rengen sub-counties of Karamoja) from 1986 to 2015 exhibited area coverage variations (Tables 2, 4 and 6).

The magnitude of LULCC and their mosaics in Iriiri, sub-county of Karamoja, for the period 1986-2015 are presented in Tables 2 and Figure 1, respectively. The results indicate that areas under different land use/cover types exhibited variations from 1986 to 2015 (Tables 2).

Grasslands (55.8\%) and farmlands (41.4\%) comprised the main land uses/cover type throughout the entire study area. The wetlands (swamps) had the least coverage (5\%). LULCC maps for Iriiri, for the year 1986, 1996, 2005 and 2015 (Figures 1 and A, B, C and D) show that the sub-county experienced rapid land use land cover changes between 1986 and 2015 (Table 2). There were high $(p<0.05)$ rise in settlement during the period under study. Settlements expanded by $71.3 \%$ from 1986 to 2015 , while other land uses did not significantly $(p<0.05)$ change during the same period (Table 3).

Grassland and farmland comprised the main land uses/cover type throughout Matany and Rengen at (66.8 and $52.0 \%$ ) and (22.2 and 13.3\%), respectively (Tables 4 and 6). The wetland (swamps) had the least coverage and occupied 0.368 and $0.636 \%$ of Matany and Rengen, respectively (Tables 4 and 6 ).

The results specified that Matany and Rengen sub-counties have rapidly undergone LULCC from 1986 to 2015 (Tables 4 and 6). Significant $(\mathrm{p}<0.05)$ land conversion was recorded in woodland in Matany sub-county. Woodland shrunk by $87 \%$ from 1986 to 2015 . Other land use conversions were not significantly high $(\mathrm{p}>0.05)$. However, in Rengen sub-county, significantly different $(\mathrm{p}<0.05)$ land conversion occurred in grassland, farmland, and woodlands. The grassland significantly decreased $(p<0.05)$ from $20,974.6$ to $12,124.7$ hectares $(42 \%)$. Farmland expanded significantly $(\mathrm{p}<0.05)$ from $5,365.3$ to $13,229.4$ hectares $(147 \%)$. On the other hand, 
woodland shrunk $(\mathrm{p}<0.05)$ from 5,235.0 to $1,003.6$ hectares $(79 \%)$. Other land uses conversion were not significantly different $\mathrm{P}<0.05$.

Generally, grassland, woodland, bare land, and wetlands shrunk while the farmland and settlement were expanding in areas they cover during study period. The final data of the bare land increase in Rengen sub-counties (Tables 3 and 5). To the contrary, the final data of bare land in Matany sub-county decreased from 2,452.5 to 303.4 hectares (87\%) (Tables 4, 5, 6 and 7).

Perhaps the study specified that farming and/or expansion of crops growing was one of the main causes of the entire study area land use changes. Probably human settlement plus the consequence of wood harvesting for construction, firewood and source of household income were the second cause of land use changes. 

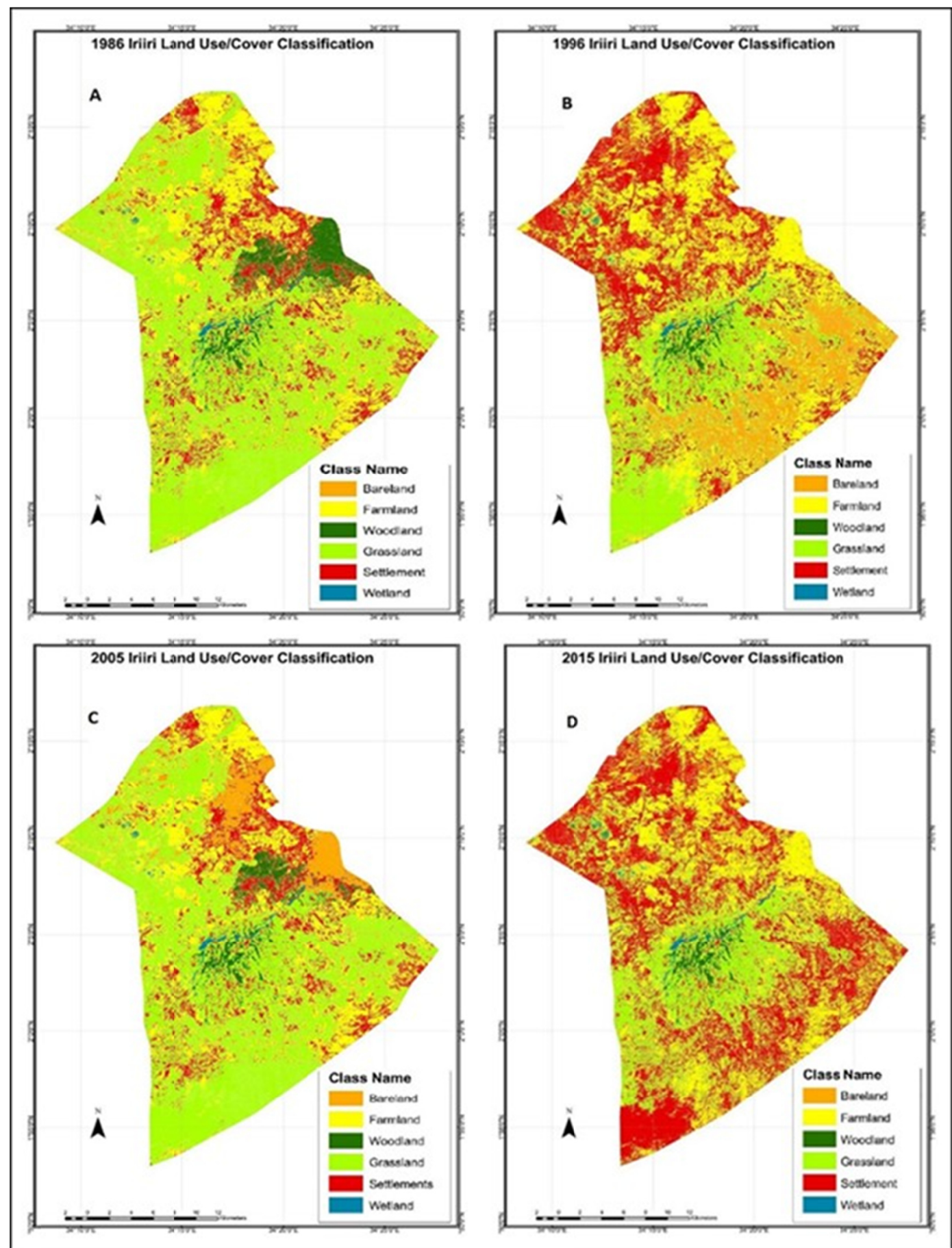

Figure 1. Land use/cover classification scheme for Iriiri sub-county for 1986, 1996, 2005 and 2015

Note. Bareland = Area without vegetation including overgrazed land, rock outcrops and erosion futures like gullies and rills; Farmland $=$ Cropping areas mainly covered by annual crops; Woodland $=$ Areas covered by woody plant species with a height of 2-10 meters; Grassland = communal grazing land with about $20 \%$ bush and mixture of scrub plant species; Settlement $=$ Homestead (Manyatta), urban and rural settlements and; Wetland = Area covered by seasonal water. 


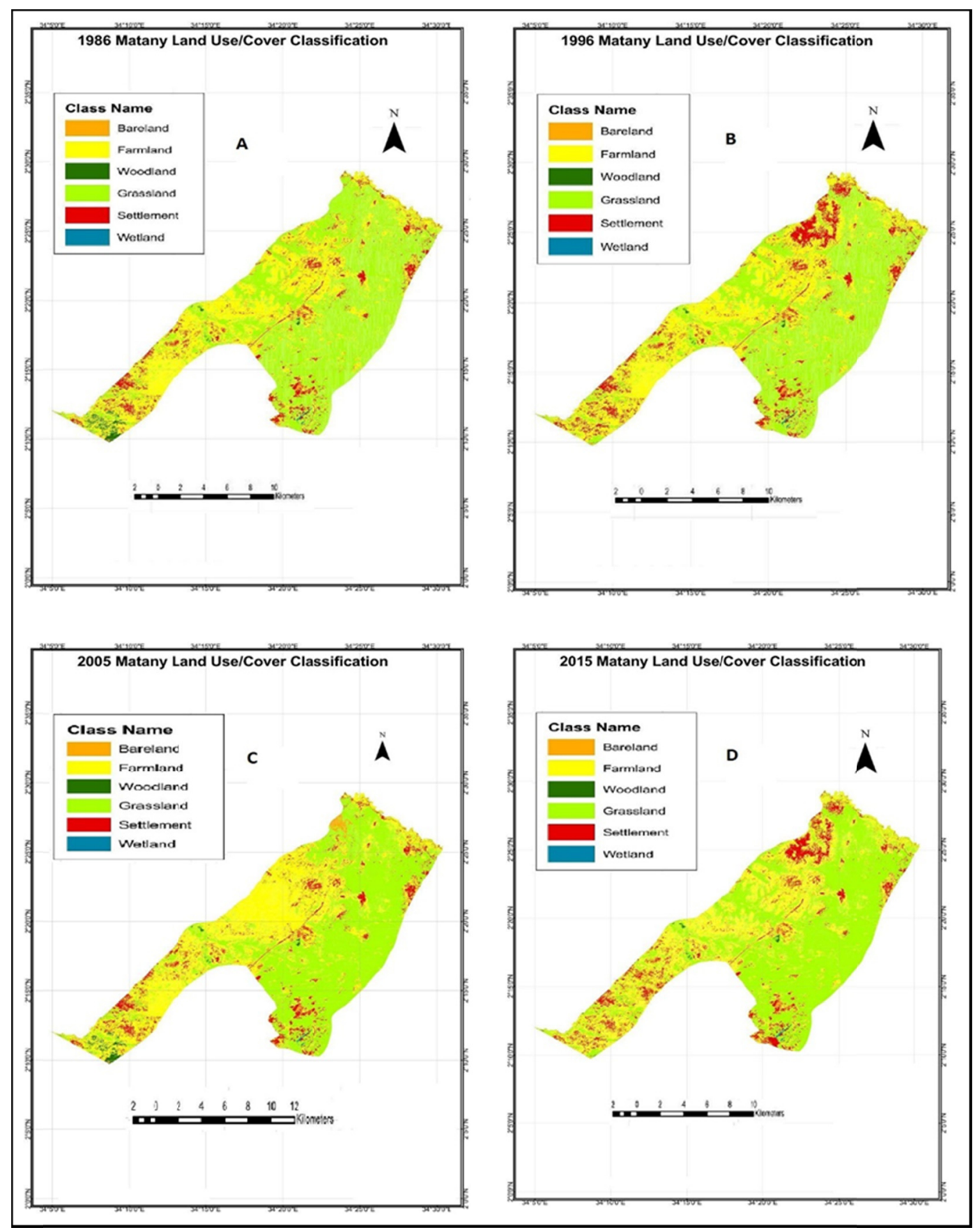

Figure 2. Land use/cover classification scheme for Matany sub-county for 1986, 1996, 2005 and 2015

Note. Bareland $=$ Area without vegetation including overgrazed land, rock outcrops and erosion futures like gullies and rills; Farmland $=$ Cropping areas mainly covered by annual crops; Woodland $=$ Areas covered by woody plant species with a height of 2-10 meters; Grassland = communal grazing land with about $20 \%$ bush and mixture of scrub plant species; Settlement = Homestead (Manyatta), urban and rural settlements and; Wetland = Area covered by seasonal water. 

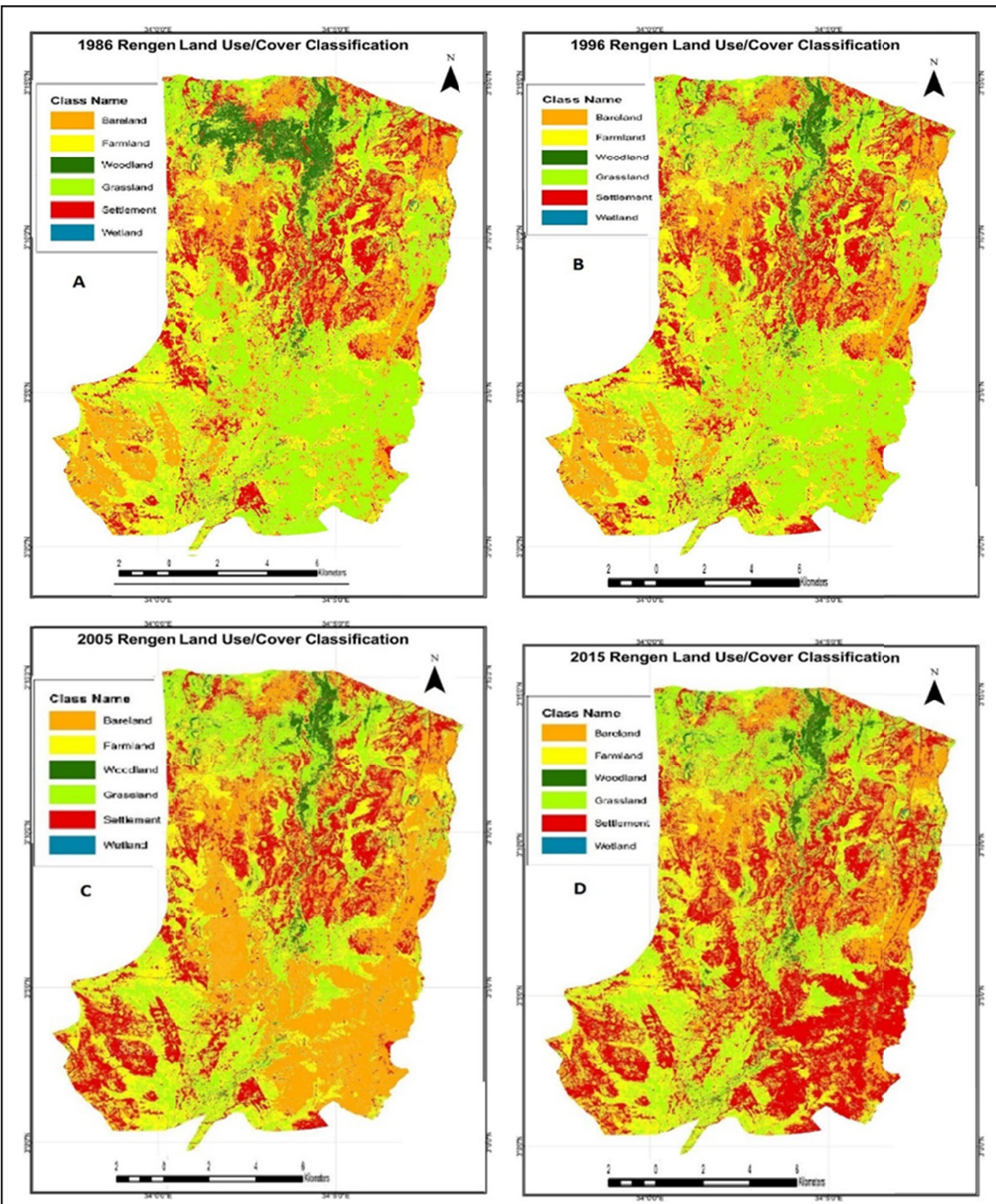

Figure 3. Land classification scheme for Rengen sub-county for 1986, 1996, 2005 and 2015

Note. Bareland $=$ Area without vegetation including overgrazed land, rock outcrops and erosion futures like gullies and rills; Farmland $=$ Cropping areas mainly covered by annual crops; Woodland $=$ Areas covered by woody plant species with a height of 2-10 meters; Grassland = communal grazing land with about $20 \%$ bush and mixture of scrub plant species; Settlement = Homestead (Manyatta), urban and rural settlements and; Wetland = Area covered by seasonal water. 


\subsection{Thematic Land Use Change Statistics From Change to Change Matrices in Iriiri Sub-county}

Table 2. Thematic land use change statistics from change to change matrices in Iriiri sub-county

\begin{tabular}{|c|c|c|c|c|c|c|c|c|c|c|c|c|}
\hline \multirow{2}{*}{$\begin{array}{l}\text { Iriiri } \\
\text { sub-county } \\
\text { LULCC } \\
\text { category }\end{array}$} & \multicolumn{2}{|c|}{1986} & \multicolumn{2}{|c|}{1996} & \multicolumn{2}{|c|}{2005} & \multicolumn{2}{|c|}{2015} & \multicolumn{4}{|c|}{ Magnitude of \% change } \\
\hline & $\begin{array}{l}\text { Area } \\
(\mathrm{Ha})\end{array}$ & $\begin{array}{l}\% \\
\text { cover }\end{array}$ & $\begin{array}{l}\text { Area } \\
(\mathrm{Ha})\end{array}$ & $\begin{array}{l}\% \\
\text { cover }\end{array}$ & $\begin{array}{l}\text { Area } \\
(\mathrm{Ha})\end{array}$ & $\begin{array}{l}\% \\
\text { cover }\end{array}$ & $\begin{array}{l}\text { Area } \\
(\mathrm{Ha})\end{array}$ & $\begin{array}{l}\% \\
\text { cover }\end{array}$ & 1986-1996 & $1996-2005$ & $2005-2015$ & $1986-2015$ \\
\hline Grassland & 41,949 . & 55.8 & $32,542.5$ & 44.8 & $30,258.6$ & 40.3 & $29,275.8$ & 39.0 & -22.4 & -7.0 & -3.3 & -30.2 \\
\hline Farmland & 17,365 & 23.1 & $20,654.8$ & 27.5 & $23,254.2$ & 31.0 & $25,103.8$ & 33.4 & 18.9 & 12.6 & 8.0 & 44.6 \\
\hline Settlement & 9,253 & 12.3 & $13,568.1$ & 18.1 & $14,963.2$ & 31.0 & $15,853.0$ & 21.1 & 46.6 & 10.3 & 6.0 & 71.3 \\
\hline Bareland & 2,137 & 2.8 & $4,255.0$ & 5.7 & $3,457.5$ & 4.6 & $3,341.6$ & 4.5 & 99.2 & -18.7 & -3.4 & 56.4 \\
\hline Woodland & 3,542 & 4.7 & $2,365.2$ & 3.2 & $2,625.2$ & 3.5 & $1,145.8$ & 1.5 & -33.2 & 11.0 & -56.4 & -67.7 \\
\hline Wetland & 872.9 & 1.2 & 623.4 & 0.8 & 561.0 & 0.8 & 399.7 & 0.5 & -28.6 & -10.0 & -28.7 & -54.2 \\
\hline Total & 75119.7 & 100 & 75119.7 & 100 & 75119.7 & 100 & 75119.7 & 100 & & & & \\
\hline
\end{tabular}

Note. LULCC $=$ Land Use Land Cover Class; $\mathrm{Ha}=$ hectares.

Table 3. Chi-square goodness of fit test for land use and land cover dynamics in Iriiri sub-county

\begin{tabular}{|c|c|c|c|c|c|c|c|}
\hline \multirow{2}{*}{ LULCC category } & \multicolumn{4}{|c|}{ Percentage land cover } & \multicolumn{3}{|c|}{ Chi-square Goodness of fii } \\
\hline & 1986 & 1996 & 2005 & 2015 & $\chi^{2}$ & df & p-value \\
\hline Grassland & 55.843 & 44.800 & 40.281 & 38.972 & 4.044 & 3 & 0.257 \\
\hline Farmland & 23.117 & 27.496 & 30.956 & 33.418 & 1.974 & 3 & 0.578 \\
\hline Settlement & 12.318 & 18.062 & 30.956 & 21.104 & 9.220 & 3 & 0.027 \\
\hline Bareland & 2.844 & 5.664 & 4.603 & 4.448 & 1.000 & 3 & 0.801 \\
\hline Woodland & 4.716 & 3.149 & 3.495 & 1.525 & 1.429 & 3 & 0.699 \\
\hline Wetland & 1.162 & 0.830 & 0.747 & 0.532 & 0.000 & 3 & 1.000 \\
\hline
\end{tabular}

Note. LULCC $=$ Land Use Land Cover Class; $\mathrm{Ha}=$ hectares. $\mathrm{p} \leq 0.05$ means significant, $\mathrm{p}>0.05$ means not significant.

\subsection{Thematic Land Use Change Statistics From Change to Change Matrices in Matany Sub-county}

Table 4. Thematic land use change statistics from change to change matrices in Matany sub-county

\begin{tabular}{|c|c|c|c|c|c|c|c|c|c|c|c|c|}
\hline \multirow{2}{*}{$\begin{array}{l}\begin{array}{l}\text { Matany } \\
\text { sub-county }\end{array} \\
\text { LULCC } \\
\text { category }\end{array}$} & \multicolumn{2}{|c|}{1986} & \multicolumn{2}{|c|}{1996} & \multicolumn{2}{|c|}{2005} & \multicolumn{2}{|c|}{2015} & \multicolumn{4}{|c|}{ Magnitude (\% change) } \\
\hline & $\begin{array}{l}\text { Area } \\
(\mathrm{Ha})\end{array}$ & $\begin{array}{l}\% \\
\text { cover }\end{array}$ & $\begin{array}{l}\text { Area } \\
(\mathrm{Ha})\end{array}$ & $\begin{array}{l}\% \\
\text { cover }\end{array}$ & $\begin{array}{l}\text { Area } \\
(\mathrm{Ha})\end{array}$ & $\begin{array}{l}\% \\
\text { cover }\end{array}$ & $\begin{array}{l}\text { Area } \\
(\mathrm{Ha})\end{array}$ & $\begin{array}{l}\% \\
\text { cover }\end{array}$ & 1986-1996 & 1996-2005 & 2005-2015 & $1986-2015$ \\
\hline Grassland & 40,185 & 67.0 & 34,241 & 56.9 & 32,26 & 53.6 & 31591 & 52.5 & -14.8 & -5.8 & -2.1 & -21.4 \\
\hline Farmland & 13,359 & 22.0 & 16,255 & 27.0 & 18,154 & 30.2 & 20381 & 33.9 & 21.7 & 11.7 & 12.3 & 52.6 \\
\hline Settlement & 3,232 & 5.4 & 5,254 & 8.7 & 6,256 & 10.4 & 7730 & 12.9 & 62.6 & 19.1 & 23.6 & 139.2 \\
\hline Bareland & 2,453 & 4.1 & 4,173 & 6.9 & 3281 & 5.5 & 303 & 0.5 & 70.3 & -21.4 & -90.8 & -87.6 \\
\hline Woodland & 689 & 1.2 & 142.4 & 0.24 & 109 & 0.2 & 88 & 0.2 & -79.3 & -23.3 & -19.5 & -87.2 \\
\hline Wetland & 221.4 & 0.4 & 72.6 & 0.12 & 810 & 0.1 & 47 & 0.1 & -67.2 & 9.9 & -42.9 & -79.4 \\
\hline Total & 60139 & 100 & 60139 & 100 & 60139 & 100 & 60138.5 & 100 & & & & \\
\hline
\end{tabular}

Note. LULCC $=$ Land Use Land Cover Class; $\mathrm{Ha}=$ hectares. 
Table 5. Chi-square goodness of fit test for land use and land cover dynamics in Matany sub-county

\begin{tabular}{|c|c|c|c|c|c|c|c|}
\hline \multirow{2}{*}{$\begin{array}{l}\text { Matany sub-county } \\
\text { LULCC category }\end{array}$} & \multicolumn{4}{|c|}{ Percentage land cover } & \multicolumn{3}{|c|}{ Chi-square Goodness of fit test } \\
\hline & $\%$ cover 1986 & \% cover 1996 & \% cover 2005 & $\%$ cover 2015 & $\chi^{2}$ & df & p-value \\
\hline Grassland & 66.820 & 56.938 & 53.641 & 52.530 & 2.126 & 3 & 0.547 \\
\hline Farmland & 22.214 & 27.028 & 30.187 & 33.890 & 2.717 & 3 & 0.437 \\
\hline Settlement & 5.374 & 8.737 & 10.403 & 12.854 & 3.541 & 3 & 0.316 \\
\hline Bareland & 4.078 & 6.940 & 5.455 & 0.505 & 4.667 & 3 & 0.198 \\
\hline Woodland & 1.146 & 0.237 & 0.182 & 0.146 & 16.667 & 3 & 0.001 \\
\hline Wetland & 0.368 & 0.121 & 0.133 & 0.076 & 3.857 & 3 & 0.277 \\
\hline
\end{tabular}

Note. LULCC $=$ Land Use Land Cover Class; $\mathrm{Ha}=$ hectares. $\mathrm{p} \leq 0.05$ means significant, $\mathrm{p}>0.05$ means not significant.

\subsection{Thematic Land Use Change Statistics From Change to Change Matrices in Matany Sub-county}

Table 6. Thematic land use change statistics from change to change matrices in Rengen sub-county

\begin{tabular}{|c|c|c|c|c|c|c|c|c|c|c|c|c|}
\hline \multirow{2}{*}{$\begin{array}{l}\text { Rengen } \\
\text { sub-county } \\
\text { LULCC } \\
\text { category }\end{array}$} & \multicolumn{2}{|c|}{1986} & \multicolumn{2}{|c|}{1996} & \multicolumn{2}{|c|}{2005} & \multicolumn{2}{|c|}{2015} & \multicolumn{4}{|c|}{ Magnitude (\% change) } \\
\hline & $\begin{array}{l}\text { Area } \\
(\mathrm{Ha})\end{array}$ & $\begin{array}{l}\% \\
\text { cover }\end{array}$ & $\begin{array}{l}\text { Area } \\
(\mathrm{Ha})\end{array}$ & $\begin{array}{l}\% \\
\text { cover }\end{array}$ & $\begin{array}{l}\text { Area } \\
(\mathrm{Ha})\end{array}$ & $\begin{array}{l}\% \\
\text { cover }\end{array}$ & $\begin{array}{l}\text { Area } \\
(\mathrm{Ha})\end{array}$ & $\begin{array}{l}\% \\
\text { cover }\end{array}$ & 1986-1996 & 1996-2005 & $2005-2015$ & $1986-2015$ \\
\hline Grassland & $20,974.6$ & 52.0 & $15,695.8$ & 40.0 & $13,254.9$ & 32.9 & $12,124.7$ & 29.3 & -25.2 & -15.6 & -8.5 & -42.4 \\
\hline Farmland & $5,365.3$ & 13.3 & $7,173.5$ & 17.8 & $8,263.1$ & 20.5 & $13,229.4$ & 32.0 & 33.7 & 15.2 & 60.1 & 146.6 \\
\hline Settlement & $4,256.9$ & 10.6 & $6,584.6$ & 16.3 & $7,025.3$ & 17.4 & $7,615.7$ & 18.4 & 54.7 & 6.7 & 8.4 & 79.0 \\
\hline Bareland & $4,256.2$ & 10.6 & $8,812.0$ & 21.8 & $10,740.1$ & 26.6 & $7,212.4$ & 17.4 & 107.0 & 21.9 & -32.9 & 69.5 \\
\hline Woodland & $5,235.0$ & 13.0 & $2,006.2$ & 5.0 & $1,003.6$ & 2.5 & $1,101.7$ & 2.7 & -61.7 & -50.0 & 9.8 & -79.0 \\
\hline Wetland & 256.5 & 0.64 & 72.4 & 1.0 & 57.4 & 0.1 & 60.6 & 0.2 & -71.8 & -20.8 & 5.7 & -76.4 \\
\hline Total & 40344.4 & 100 & 40344.4 & 100 & 40344.4 & 100 & 40344.4 & 100 & & & & \\
\hline
\end{tabular}

Note. LULCC $=$ Land Use Land Cover Class; $\mathrm{Ha}=$ hectares.

Table 7. Chi-square goodness of fit test for land use and land cover dynamics in Rengen sub-county

\begin{tabular}{|c|c|c|c|c|c|c|c|}
\hline \multirow{2}{*}{$\begin{array}{l}\text { Rengen sub-county } \\
\text { LULCC category }\end{array}$} & \multicolumn{4}{|c|}{ Percentage land cover } & \multicolumn{3}{|c|}{ Chi-square Goodness of fit test } \\
\hline & \% cover 1986 & \% cover 1996 & $\%$ cover 2005 & $\%$ cover 2015 & $\chi^{2}$ & df & p-value \\
\hline Grassland & 51.989 & 38.905 & 32.854 & 29.326 & 7.915 & 3 & 0.048 \\
\hline Farmland & 13.299 & 17.781 & 20.481 & 31.998 & 9.238 & 3 & 0.026 \\
\hline Settlement & 10.551 & 16.321 & 17.413 & 18.420 & 1.871 & 3 & 0.600 \\
\hline Bareland & 10.550 & 21.842 & 26.621 & 17.445 & 7.026 & 3 & 0.071 \\
\hline Woodland & 12.976 & 4.973 & 2.488 & 2.665 & 11.333 & 3 & 0.010 \\
\hline Wetland & 0.636 & 0.179 & 0.142 & 0.147 & 5.364 & 3 & 0.147 \\
\hline
\end{tabular}

Note. LULCC $=$ Land Use Land Cover Class; $\mathrm{Ha}=$ hectares. $\mathrm{p} \leq 0.05$ means significant, $\mathrm{p}>0.05$ means not significant.

Overall, farmland and settlement areas increased throughout the study area of Matany and Rengen sub-counties while the grassland and woodland land use areas demonstrated a shrinking trend (Figures 1, 2 and 3). Nonetheless, the wetlands were almost stable throughout the study sites and period. To the contrary, bare land demonstrated unstable trends throughout the entire study area of Matany and Rengen sub-county. Bare land in Matany shrunk tremendously by the year 2015 .

\section{Discussion}

The land use and cover changes in Iriiri, Matany and Rengen sub-counties are reflected in mainly six land uses catergories namely, grassland, farmland, settlement, bare land, woodland, and wetlands

\subsection{Grassland}

The increasing sedentary population, demand for socio-economic requirements likely increased farming, in the agro-pastoral zone are the main factors underlying the dwindling in the areas under grassland. Farmers opened 
wide chunks of land to plant crops this might have led to a reduction in the area covered by the grass. In addition, farmers harvest grass for the thatching their traditional huts, cover of wood for charcoal production and/or bricks baking in the traditional earth mound kilns, plus uncontrolled rampant bush burning were also might be responsible for the partial and temporal decrease in grassland areas. This study is in agreement with studies by Egeru et al. (2015), and Nakalembe et al. (2017), which indicate that cultivation was responsible for grassland shrinking in Karamoja districts.

\subsection{Farmland}

The observed increase in farmland size throughout the entire study area (sub-counties of Matany and Rengen), could be attributed to the reducing overdependence on livestock in the entire agro-pastoral livelihood zone of Karamoja. Extensive farming for food production started in the year 2005. People in the agro-pastoral zone started practicing agriculture in addition to livestock keeping, this coupled with the increasing population likely led to an expansion of farmland thus removal of the natural vegetation. In addition, the government of Uganda's effort to introduce sedentary agriculture in Karamoja may have acted as a driver responsible for enhanced vegetation clearance to inroduce farming. Among the government strategies to introduce more sedentary agriculture is the involvement of the Office of the Prime Minister (OPM), Non-Government Organisation (NGO) and extension workers effort to change the communities. The 2004 Karamoja Integrated Disarmament and Development Program (KIDDP) resulted into induced increase in crops growing for enhanced food production in Karamoja sub-zone (MAAIF), 2010. Increased crop production was also concluded from other literature by (Bushby and Stites, 2016). In addition, the 2002 population density of Karamoja area was as low as 12 verses 2014 which puts it at 35 persons per $\mathrm{km}^{2}$ (SUBO, 2014). Implying that previously relatively smaller population nearly solely depended on livestock for survival, but due to the increase in population, people seek alternative ways of survival. Therefore, they might have encroached on grassland and woodland for cultivation and settlement. Mainly the changes are driven by human alteration on ecological covers for socio-economic gains (Maitima et al., 2010; Ebanyat et al., 2009). Perhaps, this led to grassland and woodland decrease in hectares. In a study which was done by Nakalembe et al. (2017) in Moroto district, Karamoja, it was revealed that there were a direct competition between pasture grasses and cropland. In their study, the main drivers of the major land use changes were farming/cultivation increase, enhanced sedentary settlement, over-harvesting of wood for construction of Manyatas and the enclosures, charcoal production, bricks baking and firewood for both domestic plus household income generation. Other underlying factors are probably population increase and poverty. Similar conclusions of land use changes were drawn by Zziwa et al. (2012), Kenya Ministry of Forestry and Wildlife, 2013 and Egeru et al. (2015).

\subsection{Human Settlement}

The expansion in the settlement was probably, in part due to human population increase. For example, the human population of Rengen sub-county stood at 18,373 in 2002. In 2014 it stood at 36,977 an increase of 101\% (UBOS, 2014). Perhaps similar trends happened in Matany sub-county whose population was 22,810 in the year 2014 . Another driving force for increasing settlement may be attributed to the improved exposure of the people of Karamoja to other communities and ever-increasing levels of formal education which enables them to change to modern livelihood enhanced less nomadic livelihood. Brown et al. (2017) recorded an upward trend in education dynamics of Karamoja which required an increase in sedentary and semi-sedentary population. Human settlement (sedentary population), may account for LULCC in areas surrounding the settlements. When people settle, their population increase in the small urban centres resulting into increased trading area, whose population requires more fuel in form of firewood, charcoal, and timber for the construction of houses for accommodation as reported by FOSA Report-Uganda (2018). The above items are mainly harvested from the surrounding woodland. Perhaps, this led to increased settlement eventually resulted in the shrinking of the natural woodland and grassland covers in the study area.

\subsection{Bareland}

The highest area of bare land observed throughout the entire study area in 2005 coincided with the introduction of KIDDP which restricted livestock to protected kraals. Restricted animal grazing areas not only reduce animal movement but increase the number of livestock beyond the optimum rangeland vegetation carrying capacity. Perhaps this increased livestock overstocking leading to overgrazing which resulting in increased acreage of over trampled bare land observed in the study area. Similar observations were made in other parts of Karamoja by Burns et al. (2013). 


\subsection{Woodland}

The great shrinkage of woodland throughout the study area would probably can be attributed to the increased human activities like expanding farming or cultivation, wood harvesting for construction of Manyatta, charcoal making, bricks baking, sale to earn a living, to mention but a few.

Temporal change which included rejuvenation of woodland may be attributed to abandoning of exhausted land for fresh land by farmers and recovery of wood tree species from human wood harvesting for houses construction, charcoal, and firewood. Similarly, woodland increase in area from the years 2005 to 2015 might have regained some area as a recovery from the previous overgrazed land due to previously restricted grazing from the protected kraal era. This is in line with a study which was done by Islam et al. (2001) in the tropics of Bangladesh where an increase in exotic shrubs and grasses were recorded after deforestation.

\subsection{Wetland}

The wetland changes could be attributed to seasonal variations and unpredictable rainfall, other than human encroachment. The area covered by seasonal water depends on the availability and the amount of rainfall received during the season and the drought experienced in the area. Prolonged dry season might have manifested its self in a reduced area covered by the wetland and the reverse is true. Similarly, Mubiru, (2010) attributed the water shortages to seasonal rainfall variability.

Overall agriculture or farming increased at an alarming rate. Although Karamoja is lightly populated, most of them are clustered near urban centres for security purposes. In this regard, areas near urbanizing centres were likely to be more vulnerable to loss of vegetation due to human settlement and their subsequent requirements. These might have culminated into changing natural forests and grassland covers and hence environmental degradation which requires further studies. Nakalembe et al. (2017) recorded a high increase in crops production in Lotome sub-county Napaka district of Karamoja.

The study results indicated that there was a sharp decline in woodland hectares. This may be ascribed to increased human demands for survival leading to over cutting of trees for use in charcoal production, firewood, bricks baking, huts building, thatching and bush clearing for crop production. The study was in agreement with earlier studies which were conducted in Ethiopia by Olson et al. (2004), and Berhanu et al. (2016).

\section{Conclusions}

The findings of this study have demonstrated occurrence of substantial LULCC dynamics between the years 1986 and 2015. The study further established that in each of the sub-counties (Iriiri, Matany and Rengen) farmland increased while woodland and grassland shrunk; as such farming was the main LULCC of which was studied. Perhaps, advocacy for sedentary farming was one of the main drivers of LULCC in the agro-pastoral zone. Probably the population increase with its consequences like wood harvesting for domestic use and household income also resulted into enhanced land use changes. Studies on LULCC and their effect on soil quality at sub-counties level are crucial in guiding land use planning, policy makers and other stakeholders for sustainable management practices in the area.

\section{Acknowledgements}

National Agricultural Research Organisation, Uganda for funding.

The sub-counties chiefs, local elders and the Agricultural Extension Officers of Rengen and Matany Iriiri sub-counties for the assistance offered during the study.

\section{References}

Berhanu, Y., Negatu, L., Beyene, F., \& Angassa, A. (2016). Impact of resettlement on vegetation status and rangeland condition in southwestern Ethiopia. African Journal of Agricultural Research, 11(7), 533-542. https://doi.org/10.5897/AJAR2015.10526

Brown, V., Marion, K., \& Travor, M. (2017). Education System in Karamoja Karamoja Resilient Support Unit. Retrieved from http://www.karamojaresilience.org/publications?task=callelement\&format

Burns, J., Bekele, G., \& Akabwai, D. (2013). Livelihood Dynamics in Northern Karamoja. Technical Report of Feinstein International Centre.

Bushby, K., \& Stites, E. (2016). Resilience and Risk in Pastoralist Areas: Recent Trends in Diversified and Alternative Livelihoods, Karamoja, Uganda (p. 11).

Cui, X., Gibbes, C., Southworth, J., \& Waylen, P. (2013). Using remote sensing to quantify vegetation change and ecological resilience in a semi-arid system. Land, 2(2), 108-130. https://doi.org/10.3390/land2020108 
Dirmeyer, P. A., Niyogi, D., de Noblet-Ducoudré, N., Dickinson, R. E., \& Snyder, P. K. (2010). Impacts of land use change on climate. International Journal of Climatology, 30(13), 1905-1907. https://doi.org/10.1002/ joc. 2157

Ebanyat, P., de Ridder, N., De Jager, A., Delve, R. J., Bekunda, M. A., \& Giller, K. E. (2010). Drivers of land use change and household determinants of sustainability in smallholder farming systems of Eastern Uganda. Population and Environment, 31(6), 474-506. https://doi.org/10.1007/s11111-010-0104-2

Egeru, A., Wasonga, O., Macopiyo, L., Mburu, J., \& Majaliwa, M. G. (2015). Abundance and diversity of native forage species in pastoral Karamoja sub-region, Uganda.

ESRI (Environmental Systems Research Institute) (2009). ENVI 4.7 and ENVI EX. ITT Visual Information Solutions. ESRI, Redlands, California, USA.

Fan, F., Weng, Q., \& Wang, Y. (2007). Land use and land cover change in Guangzhou, China, from 1998 to 2003 , based on Landsat TM/ETM+ imagery. Sensors, 7(7), 1323-1342. https://doi.org/10.3390/s7071323

FOSA Country Report-Uganda. (2018). Retrieved June 7, 2018, from http://www.fao.org/docrep/004/AC427E/ AC427E08.htm\#TopOfPage

Fox, J. T., Vandewalle, M. E., \& Alexander, K. A. (2017). Land Cover Change in Northern Botswana: The Influence of Climate, Fire, and Elephants on Semi-Arid Savanna Woodlands. Land, 6(4), 73. https://doi.org/ $10.3390 /$ land 6040073

Hassan, Z., Shabbir, R., Ahmad, S. S., Malik, A. H., Aziz, N., Butt, A., \& Erum, S. (2016). Dynamics of land use and land cover change (LULCC) using geospatial techniques: A case study of Islamabad Pakistan. Springer Plus, 5(1), 812. https://doi.org/10.1186/s40064-016-2414-Z

Islam, K. R., Ahmed, M. R., Bhuiyan, M. K., \& Badruddin, A. (2001). Deforestation effects on vegetative regeneration and soil quality in tropical semi-evergreen degraded and protected forests of Bangladesh. Land Degradation \& Development, 12(1), 45-56. https://doi.org/10.1002/ldr.418

Islam, K., Jashimuddin, M., Nath, B., \& Nath, T. K. (2016). Quantitative Assessment of land cover change using landsat time series data: Case of Chunati Wildlife Sanctuary (CWS), Bangladesh. International Journal of Environment and Geoinformatics, 3(2), 45-55. https://doi.org/10.2139/ssrn.2819764

Kyagulanyi, J., Kabenge, I., Banadda, N., Muyonga, J., Mulamba, P., \& Kiggundu, N. (2016). Estimation of spatial and temporal water requirements of grain amaranth using satellite, local and virtual weather stations datasets in Uganda. Journal Agric. and Bio Eng., 9(2), 85.

Lowrance, R., Altier, L. S., Newbold, J. D., Schnabel, R. R., Groffman, P. M., Denver, J. M., \& Staver, K. W. (1997). Water quality functions of riparian forest buffers in Chesapeake Bay watersheds. Environmental Management, 21(5), 687-712. https://doi.org/10.1007/s002679900060

MAAIF. (2010). MAAIF Statistical Abstract. Technical Report Ministry of Agriculture, Animal Industry and Fisheries, Uganda.

Maitima, J. M., Mugatha, S. M., Reid, R. S., Gachimbi, L. N., Majule, A., Lyaruu, H., \& Mugisha, S. (2009). The linkages between land use change, land degradation and biodiversity across East Africa. African Journal of Environmental Science and Technology, 3(10).

Ministry of Forestry and Wildlife. (2013). Analysis of drivers and underlying causes of forest cover change in the various forest types of Kenya. Consultancy Services Provided by Ruri Consultants, Nairobi, Kenya. Retrieved July 19, 2013, from http://www.kenyaforestservice.org/documents/redd/Analysis\%20\%20of\%20 Drivers\%20of\%20Deforestation\%20\&forest $\% 20$ Degradation $\% 20$ in $\% 20$ Kenya.pdf

Mubiru. (2010). Climate change and adaptation options in Karamoja. Retrieved from http://www.fao.org/ fileadmin/user-upload/drought/docs/1-Karamoja\%20Climate $\% 20$ Change $\% 20$ and $\% 20$ Adaptation $\% 20$ Optio ns.pdf

Mwavu, E. N., \& Witkowski, E. T. F. (2008). Land-use and cover changes (1988-2002) around Budongo Forest Reserve, NW Uganda: Implications for forest and woodland sustainability. Land Degradation \& Development, 19(6), 606-622. https://doi.org/10.1002/ldr.869

Nakalembe, C., Dempewolf, J., \& Justice, C. (2017). Agricultural land use change in Karamoja Region, Uganda. Land Use Policy, 62, 2-12. https://doi.org/10.1016/j.landusepol.2016.11.029 
Rugadya, M. A., \& Kamusiime, H. (2013). Tenure in Mystery: the Status of Land under Wildlife, Forestry and Mining Concessions in Karamoja Region, Uganda. Nomadic Peoples, 17, 33-65. https://doi.org/10.3167/ np.2013.170103

Statistics, U. B. O. (2014). National Population and Housing Census 2014. Kampala: Uganda Bureau of Statistics. Retrieved from http://www.ubos.org/onlinefiles/uploads/ubos/NPHC/NPHC

Sundarakumar, K., Harika, M., Begum, S. A., Yamini, S., \& Balakrishna, K. (2012). Land use and land cover change detection and urban sprawl analysis of Vijayawada city using multitemporal landsat data. International Journal of Engineering Science and Technology, 4(01), 170-178.

UBOS. (2014). Uganda National Population and Housing Census. Retrieved from http://www.ubos.org/ onlinefiles/uploads/ubos/NPHC/NPHC\%202014\%20PROVISIONAL\%20RESULTS\%20REPORT.pdf

USAID. (2017). Climate Risk Screening for Food Security Karamoja Region, Uganda. Retrieved from https://www.usaid.gov/sites/default/files/documents/1866/170130_Karamoja_Food_Security_Climate_Scre ening.pdf

USGS (United States Geological Survey). (n.d.). Retrieved from https://www.usa.gov/federal-agencies/u-sgeological-survey

Weather 2. (2018). Moroto Climate History: Past Weather Including Monthly Averages for Moroto Uganda.

Zziwa, E., Kironchi, G., Gachene, C., Mugerwa, S., \& Mpairwe, D. (2012). The dynamics of land use and land cover change in Nakasongola district. Journal of Biodiversity and Environmental Sciences, 2(5), 61-73.

\section{Copyrights}

Copyright for this article is retained by the author(s), with first publication rights granted to the journal.

This is an open-access article distributed under the terms and conditions of the Creative Commons Attribution license (http://creativecommons.org/licenses/by/4.0/). 